\title{
Big Data Analytics Usage and Business Performance: Integrating the Technology Acceptance Model (TAM) and Task Technology Fit (TTF) Model
}

\author{
Hemlata Gangwar \\ Pune Institute of Business Management, India \\ hemlata.gangwar@pibm.in \\ DOI: 10.34190/EJISE.20.23.1.004
}

\begin{abstract}
The purpose of this study is to propose a unified model integrating both the technology acceptance model (TAM) and task technology fit (TTF) model, and explore the organizational and environmental fit of the integrated model in order to investigate usage of Big Data Analytics and its effect on business performance. A questionnaire was used to collect data from 280 companies in CPG \& Retail, Healthcare, Banking and Telecom in India. The data were analysed using exploratory and confirmatory factor analyses. Further, structural equation modelling was used to test the proposed model. The findings show that the research model for integrating the TAM for adoption and TTF model for utility provides a more comprehensive understanding of Big Data Analytics usage. The study identified task technology fit, individual technology fit, organizational data fit, organizational process fit, and business strategy fit as Tidd important variables for affecting Big Data Analytics usage using perceived ease of use (PEOU) and perceived usefulness (PU) as mediating variables. Competitive fit and partner support/customer fit were also found to be directly affecting Big Data Analytics usage, which in turn has significant influence on business performance. The model explained 71.4 percent of Business performance. The integrated model may be used as a guideline to ensure a positive outcome of Big Data Analytics usage in organizations. This study combined both the key ideas of TAM and TTF to show that they were necessary in predicting Big Data Analytics usage and business performance.
\end{abstract}

Keywords: Big Data Analytics, Technology Acceptance Model, Task Technology Fit, Technological Fit, Organizational Fit, Environmental Fit

\section{Introduction}

'Big Data' and 'Big Data Analytics' have become important globally both in academics and business; they enable real-time data analysis with minute precision in order to arrive at key decisions based on evidence rather than intuition. Manyika et al. (2012) defined Big Data Analytics as "the amount of data just beyond technology's capability to store, manage, and process efficiently." According to Hashem et al. (2015) "Big Data Analytics is a set of techniques and technologies that require new forms of integration to uncover large hidden values from large datasets that are diverse, complex, and of a massive scale." In addition, NIST defines Big Data Analytics as "the data of which the data volume, acquisition speed, or data representation limits the capacity of using traditional relational methods to conduct effective analysis or the data which may be effectively processed with important horizontal zoom technologies." This study looks at Big Data Analytics as a blend of infrastructure and technology of an organization, which collects stores and analyses various types of data. Further its additional advantage and biggest value-creation is in its inherent ability to use advanced analytical techniques, which earlier could not be processed using the traditional database.

The advantages of Big Data Analytics are manifold including better decision making, better 'targeted' marketing, much improved client based support, direct and stringent business insights, better planning and forecasting among several others (Chen and Zhang., 2014; Nimmagadda, Reiners and Wood, 2018) However, despite having several strategic and operational advantages, it has been observed that the adoption rate of Big Data Analytics within industries and sectors at large hasn't been impressive (Shin 2016). Thus further research is needed in order to understand the inertia coupled with the risk and challenges affecting large scale adoption; having said that, it's imperative to note that there's a lot of research that is on-going in the technology itself, wherein scholars and exponents of this technology are working together in order to address some plaguing businessrelated issues of Big Data Analytics (Chen, Mao and Liu, 2014; Verma, Bhattacharyya and Kumar, 2018). Whilst some studies have been focusing on the risks and opportunities of adopting Big Data, without getting into details on the importance and effectiveness of adoption factors, there are others, who are looking to investigate factors that influence the use of Big Data, whereas research on factors influencing Big Data Analytics usage and its impacts on business performance is also required. Further, in the domain of organizational studies, considerable 
thought to understanding the technological organizational environmental fit perspective which influence organizational effectiveness, and create a connection between fit and performance is needed (Goodhue and Thompson, 1995). This paper considers the role of task-technology fit, individual technology fit, data fit, process fit and strategy fit in Big Data Analytics success, and addresses the question of how task-technology fit influences the performance of Big Data; it also addresses the effect of competitor fit and customer/ partner fit on Big Data Analytics usage and business performance.

Further, the current study aims to identify whether and to what extent the above mentioned factors influence Big Data Analytics usage and business performance relative to the two stages (i.e. TAM and TTF). Thus, this paper presents a research framework for integrating the technology acceptance model (TAM) for the usage of Big Data Analytics and the task fit technology model (TTF) for its utility. The rest of this paper has been organized as follows: literature review forms Section 2 of the paper, which initially discusses both TTF and TAM, and then talks about the integration of both TAM and TTF; the Research model is presented in Section 3, followed by a discussion of the research design and methodology in Section 4. The most relevant findings obtained from this study are presented and discussed in Section 5. Finally Section 6 draws conclusions and summarizes the contributions of this study as a whole.

\section{Literature Review}

\subsection{Big Data Analytics Adoption}

Big Data, often referred as massive dataset in terms of volume, velocity and variety requires new forms of processing for better insights. Gartner defined Big Data Analytics as "high-volume, high-velocity and high-variety information assets that demand cost-effective, innovative forms of information processing for enhanced insight and decision making." It's rapidly becoming a major driver for firms seeking to gain a competitive advantage, increasing operational efficiency, enhanced strategic directions, developing better customer service, identifying and developing new products, services, new customers and markets. 'Big Data Analytics' may be seen as an innovative IT capability to improve a firm's performance through database searching, mining, and analysis; it could be referred as the techniques, technologies, system, methodologies, tools and applications that analyse excessive variety of critical business data to make timely efficient and effective decision making (Gandomi and Haider 2015; Mcafee and Brynjolfsson 2012). Some of the salient Big Data Analytics techniques include text analysis, audio analysis, video analytics, social media analytics, and predictive analytics. Though some leading companies are actively adopting Big Data Analytics specifically in order to enhance decision making and reducing business costs, many companies are still at a nascent phase as regards Big Data Analytics adoption due to their lack of understanding.

Many studies have addressed the technical and operational issues related to Big Data, including issues such as Creating value from Big Data Analytics(Chen, Mao and Liu, 2014; Chen and Zhang 2014; Jagadish et al.,2014), data processing framework for data storage and analysis (Wu et al., 2014; Chen, Chiang and Storey, 2012), issues related to data transformation, data quality/heterogeneity, security, privacy and legal/regulatory issues (AlShomrani, Eassa and Jambi, 2017; Hu and Vasilakos 2016; Hashem et al., 2015; Kshetri, 2014; Bates et al., 2014).Only a few studies have looked to evaluate Big Data Analytics adoption from an organisational perspective. Sun et al., (2016) developed a conceptual framework to identify the factor affecting organisational adoption of Big Data. Their framework isn't extensive as the factors are explored only from a theoretical perspective based on content analysis of IT adoption literature. Thus it is amply clear that empirical research is needed for a better explanation of the adoption of Big Data Analytics at an organizational level. Kwon, Lee and Shin, 2014 developed a research model using the resource view with Isomorphism theories to explain the intention to adopt Big Data Analytics; the result concluded that data quality and data usage benefits were the most important indicators for Big Data Analytics adoption. Chaurasia and Rosin (2017) examined the applicability of Big Data Analytics in higher education institutions; using Qualitative methodology, they identified four major application areas (i.e. reporting and compliance; analysis and visualization; security and risk mitigation; and predictive analytics). Verma and Bhattacharyya (2017) at their end, identified factors that influence Big Data Analytics usage and adoption in the context of emerging economies by using a qualitative exploratory study opting for face-to-face semi-structured interviews in order to collect data from 22 enterprises in India. Verma, Bhattacharyya and Kumar, 2018 covers Big Data Analytics adoption through testing the effects of system characteristics on the attitude of managers using TAM model. Despite these efforts from scholars in the past, it could be confirmed that no study has taken a holistic approach to empirically validate the technology fit, organization fit, and environment fit perspective. This study therefore integrated TAM and TTF models to 
study the effect of technology fit, organization fit, and environment fit on Big Data Analytics usage and business performance.

\subsection{Task Technology Fit}

Contingency theory posits that organisational performance depends upon its fit between an organisation and contingencies. Donaldson (2001) defined contingency as a "factor that moderates the effect of an organizational characteristic on organizational performance." Extant literature has identified various contingencies such as technology, innovation, environmental change, size, culture, business technology strategy, and structure in different IT implementation processes (Weill and Olson 1989; Teo and Pian2 003; Morton and Hu 2008; Hung et al. 2011; Hernandez-Ortega, Serrano-Cinca, and Gomez-Meneses, 2014). Initially, researchers applied the contingency theory to study environment-structure-performance relationship for organisations (Miller and Friesen, 1983; Ruekert, Walker and Roering, 1985), with an assumption that no single organisation structure can be effective under all circumstances, no single strategy would be applicable to dynamic, growing and stable environmental characteristics of the environment in which it operates in order to deliver competitive advantage. Therefore better the fit between contingency and an organisation, higher the organisational performance in terms of efficiency and effectiveness (Tidd, 2001; Huang, Janz and Frolick 2008; Volberda et al. 2012). According to Buttermann, Germain and lyer (2008), the Contingency theory is used to predict performance on the basis of the fit of information technology to strategy, organisational structure with environmental unpredictability.

The introduction of the Contingency theory in Information system gave rise to the concept of fit, which grew continuously in measuring performance of a technology. Goodhue and Thompson (1995) thereby proposed the task technology fit model in order to highlight the importance of fit between technology and individual task to achieve individual performance due to technology. Some studies (Keller, 1994; Goodhue and Thompson 1995 Khazanchi, 2005) applied both contingency and task-technology fit theory in the adoption of information system, suggesting that information system performance depends on the fit between a task and technology. Mcgill and Klobas (2009) defined task-technology fit as "the degree to which a technology assists an individual in performing his or her portfolio of tasks." Teo and Men (2009) investigated the utilization of KM technologies from the task-technology fit (TTF) perspective and found that knowledge tacitness, output quality, and compatibility are important for knowledge utilization. Lin and Wang (2011) on the other hand integrated contingency theories and task-technology fit theory to investigate the intention of learner in adopting e learning system. Results show that the information quality and task-technology fit do influence system acceptance. Parkes (2013) in the same direction, explored fitting technology to the task and user affects technology performance. Tam and Oliveira (2016) from their end proposed a model based on Task Technology Fit (TTF) model to evaluate the impact of m-banking on individual performance. Although TTF has been actively researched and applied to a wide range of information systems (Wu and Chen, 2017; Aljukhadar, Senecal, and Nantel, 2014), it is still unclear on what factors affect technology-driven performance based on the Task Technology Fit (TTF) model. To fill these voids, this study extends the TTF model to organization technology fit and environmental fit perspective. The TTF model does not address jointly task technology fit, organization technology fit and environmental fit which may limit its predictive ability for technology. The limitation can be overcome by extending it with technological, organizational and environmental fit perspective.

\subsection{Technology Acceptance Model}

TAM was developed by Davis (1986) to investigate the link between the actual use of the new technology and the behavioural intention to use the technology. TAM assumes that individual/organisation information system is determined by two major construct that is perceived usefulness (PU) and perceived ease of use (PEOU). PU defined as "the degree to which a person believes that his/her job performance would be enhanced by using a particular technology" and PEOU as "the degree to which a person believes that using the technology requires less mental efforts". TAM is the most widely used model in IT adoption literature (Hong, Thong and Tam, 2006; Grandon and Pearson 2004; Park and Chen 2007; Basoglu, Daim and Kerimoglu, 2007; Wu 2011; Sharma, Govindaluri and AlBalushi, 2015). The TAM model is used extensively for successfully predicting and explaining users' intentions to adopt technologies. This research therefore employed the TAM model and extended it by including the task technology fit and organization fit variables.

\subsection{Integration of Technology Acceptance Model and Task Technology Fit Model}

Both the Technology Acceptance Model (TAM) and Task-Technology Fit (TTF) have been at the vanguard of Information Technology Adoption literature. While TAM only focuses on attitudes toward using a particular IT 
tool developed by users based on perceived usefulness and ease of use, the TTF model pivots on the idea of having a good fit of functional capabilities and task requirements leading thereby to higher performance. Extant literature has shown that TAM lacks in task focus and thereby isn't able to explain the capabilities needed for a task (Lee and Lehto, 2013).The TTF model on the other hand takes a more rational approach by assuming that users choose to use IT tools that enhances job performance for instance, regardless of their attitude toward IT as a whole. Attitude towards using IT expected consequences from using the IT can affect user's choice to utilize it, lacks in TTF model. Integrating both the model can thereby provide a better explanation of IT utilisation by overcoming these limitations. Some studies have combined the TAM and TTF models to increase the explanatory power (Pagani , 2006; Chang, 2008; Närman et al., 2012; Lee and Lehto 2013; Wu and Chen, 2017). Earlier it has been observed that integrated TAM and TTF models aren't homogeneous; as a matter of fact, some studies have in fact included the aspect of 'attitude toward use.' For example Lee and Lehto (2013) on integrating both TAM and TTF found that the integrated model is indeed task-technology fit, is rich in content, and is vivid. Wu and Chen (2017) on the other hand while integrating both models, identified that the perceived ease of use, task-technology fit, reputation, social recognition and social influence do have important roles in predicting the intention of continuance. Huang, Wu and Chou (2013) integrated TAM and TTF using task-technology fit, user satisfaction, perceived usefulness, and continuance of the intention to use. However, there have been no studies investigating the problem of the use of technology in a robust manner, which considers the three perspectives in amalgamation (i.e. task technology fit, organizational fit and environmental fit).

\section{Proposed framework}

Based on extant literature, adoption variables relevant to Big Data Analytics have been selected to propose a conceptual framework followed by their hypotheses.

Technological Fit

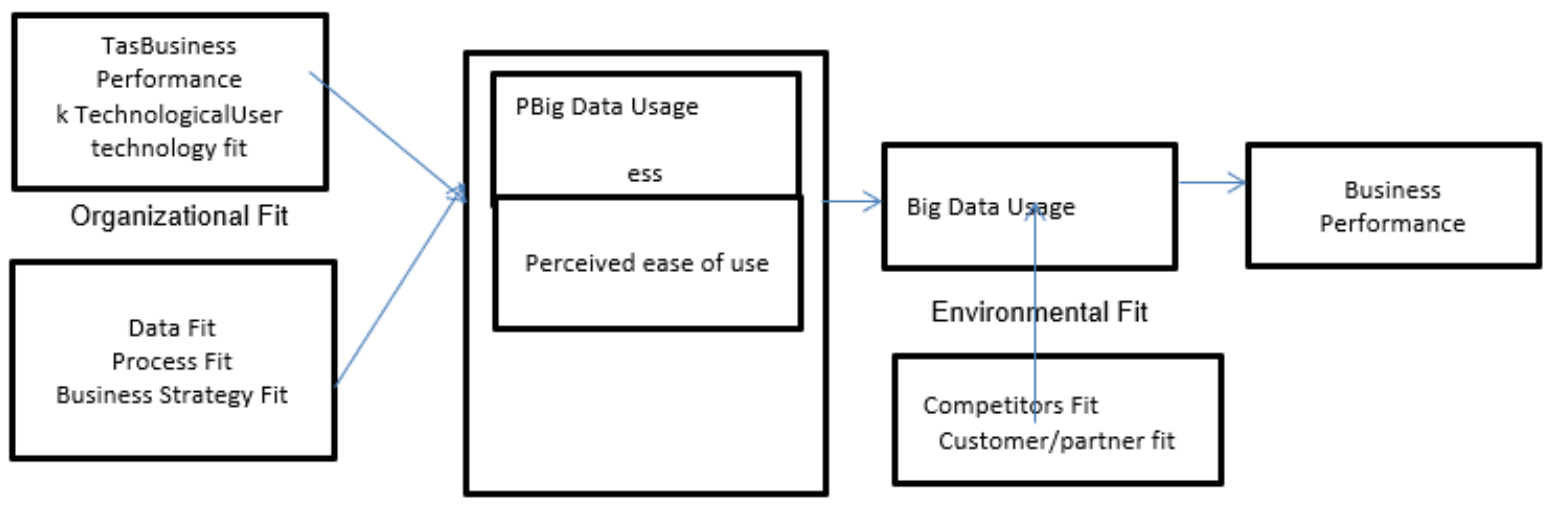

Figure 1: Proposed research model. (adopted from Davis 1986 and Goodhue and Thompson 1995)

\subsection{Technological Fit}

Technological fit determines how a technology is appropriate for a task that a user needs to perform, and is attributed to individual users, which ultimately affects job performance. This factor refers to the importance of technology on an individual's current task accomplishments and individual attribute of users, such as knowledge and skills required completing a task. The TTF model suggests that task-technology fit is a function of two components: fit between individuals and technology and fit between task and technology.

\subsubsection{Task Technology Fit}

According to Goodhue and Thompson (1995), task characteristics refer to activities carried out by individuals in revolving inputs into outputs. It is related to task complexity, which in turn has to be supported by an IT system along with the functionality of technology in order to support a complex task. Earlier, companies using Big Data Analytics were not able to derive meaningful insights timely, predict and respond to changing consumer needs as there wasn't any efficient way to extract data and thereby streamline it.

Additionally, traditional database have limits on data volume and variety. It's important to understand that Big Data Analytics primarily helps companies identify the services that customers want, often customising them to generate new customer demands, build effective and targeted promotions by correlating customer purchase 
history, customer profile data, and customer behaviour (Somal, 2017). The main goal for almost all organisations is to enhance customer experience, reduce cost, make existing processes more efficient, better targeted marketing, competitive offering and finally, better decision making. With data analytics all of this and much more could be done as it has made it easier to monitor and evaluate the progress of companies by constantly monitoring clients' behaviour in real time. Thus the fit between task and technology thereby influences perceived usefulness and perceived ease of use. When the fit between task and technology is higher, the user perceives technology to be useful and thereby it is easier to use for a task.

Thus, the following research hypotheses are proposed:

H1. Task-technology fit has a positive effect on the perceived usefulness of Big Data Analytics.

H2. Task-technology fit has a positive effect on the perceived ease of use of Big Data Analytics.

\subsubsection{Individual Technology Fit}

An organisation's effective use of Big Data Analytics depends on factors associated with individual-technology fit, including whether an individual's knowledge and analytical skills match the skill required, using Big Data Analytics in order to support analysis and decision-making, and thus asses weather Big Data Analytics technology matches as a key component to their day to day decision making process. Thus it is important to look at whether individual users of an organisation adopting the new technology properly if they are slow then organizational adoption of technology may fail. However individuals are often motivated to adopt new technologies in a drive to improve their performance and skill set which is required to be competitive in the market (Wu and Chen, 2017). Higher the individual-technology fit, greater the perceived usefulness and perceived ease of use, because more knowledgeable and expert users are better able to understand the usefulness of Big Data Analytics technology. Then individuals who hold that skillset and knowledge, may actually find the ease of use while using it.

Thus, the following research hypotheses are proposed:

H3. Individual-technology fit has a positive effect on the perceived usefulness of Big Data Analytics.

H4. Individual-technology fit has a positive effect on the perceived ease of use of Big Data Analytics.

\subsection{Organisational Fit}

The concept of organisational fit is important in understanding the factors contributing to the success of different IT implementation processes. It is defined as the consistency between technology and organisational environment and is related to business strategy, organisational structure, management processes, and data environment fit for an effective and efficient use of technology (Hung et al. 2011). Thus, this study focuses on the process of achieving Big Data Analytics implementation from the perspective of organisational fit, which includes issues of change management in business processes, synergy of IT and business strategies, and collaboration of data definition standards coupled with data integrity and security policies.

\subsubsection{Organisational data Fit}

Data fit depends on organisational data environment and Big Data. Drive for fit between technology and existing data environment can be achieved through sophisticated Data Resource Management, which includes planning, standards, quality, availability, integrity, reliability and security policies (DeLone and McLean 1992; Wixom and Watson 2001; Ramamurthy, Sen and Sinha, 2008). The objective of Big Data Analytics is to analyse internal and external data in order to improve the efficiency and effectiveness of every decision. The effectiveness also relies on an organisation having the proper data resource management; it is also determined by whether the data format along with the input and output data of Big Data Analytics are integrated directly with data in the organisation. In addition, better fit between existing formats, interfaces, and other structured data result in higher usage of Big Data. On the other hand, lesser fit between existing data environment and Big Data Analytics results in inaccessibility of information and thereby is a difficult proposition for data integration.

Thus, the following research hypotheses are proposed:

H5. Organisation data fit has a positive effect on the perceived usefulness of Big Data Analytics.

H6. Organisation data fit has a positive effect on the perceived ease of use of Big Data Analytics.

\subsubsection{Organisational Process Fit}

Organisations must effectively align their processes and structures with technology to perform effectively (Rogers, Miller and Judge, 1999). Therefore, process standardisation is desirable, which in turn offers technical 
interchange ability, compliance with regulations to support standardised tasks by the technology (Trkman, Peter 2010).Generally, standard business processes define rules, policies, and operating procedures, which are formalised and followed to perform task through technology (Jang and Lee 1998); thus business processes must also be changed and standardised through training and learning in order to allow the technology to operate effectively. The objective is achieving a standardised process matching the capabilities of technology in order to support a collection of activities or tasks in the process. On the other hand, Big Data Analytics should be changed and customised in a way so as to fit the organisational process as a whole. This research thereby argues that organisations having the ability to customise and integrate Big Data Analytics have also the ability to change or redesign business processes, which in turn would increase the use of Big Data. The fit therefore between process and Big Data Analytics offers easier use of technology through way to augment and extend its application reach.

On the basis of these discussions, the following research hypotheses are proposed:

H7. Organisational process fit has a positive effect on the perceived usefulness of Big Data Analytics. H8. Organisational process fit has a positive effect on the perceived ease of use of Big Data Analytics.

\subsubsection{Business strategy Fit}

Technology matters to business success if it is integral to a firm's business-level strategy because it directly affects the mechanisms through which it creates value. Business-level role of technology indicates the need for re-theorising its role in strategy and its relationship with mechanisms through which organisations generate profit (Drnevich and Croson, 2013; Coltman et al., 2015). When an organisation realises the strategic importance of technology in improving business performance, it is only then it would take the initiative to use it; for example, if data analysis is a crucial aspect of organisational business strategy, then Big Data Analytics turn out to be a key component of their day to day decision making, thereby improving the overall business performance. Better fit of technology with a business strategy addresses mutual understanding of and commitment to technology and business objectives and plans among business and IT executives. Better fit between business strategy and Big Data Analytics would make organisations more competitive, and the technology that is used, would be perceived to be easy and more meaningful when it comes to the day to day decision making processes.

Thus, the following research hypotheses are proposed:

H9. Business strategy fit does have a positive effect on the perceived usefulness of Big Data Analytics. H10. Business strategy fit does have a positive effect on the perceived ease of use of Big Data Analytics.

\subsection{Environmental Fit}

The environmental context defines the arena within which a firm operates and competes (Prajogo I., 2016; Gangwar, Date and Ramaswamy, 2015; Tsai andYang, 2013), in turn influencing the effectiveness of technology, which may be effective in certain environments and may not be in others. Thus, environmental conditions can and often does affect the performance of technology; as a result, managers must look for the best fit between technology and environmental conditions. Environmental conditions therefore, related to business partners and customers can affect usage and performance of technology (Yang and Meyer, 2015).

\subsubsection{Competitive Fit}

Extant literature showed that competitive environments create the dynamics to use technology, because ultimately it's the competitors who instigate the use of technology in order to an cash its benefits, wherein the organisation feels the pressure to replicate the same just in order to remain competitive (Low, Chen and Wu, 2011; Gangwar, Date and Ramaswamy, 2015; Yang and Meyer, 2015; Prajogo D.I. 2016). This study defines competitive fit to be the fulcrum based on which an organisation achieves substantial competitive advantage, especially by using Big Data Analytics (Lin 2014b; Jia, Guo and Bames, 2017). Therefore, the next hypothesis is thus:

H11: Competitive fit is positively associated with the use of Big Data.

\subsubsection{Partner/customer Fit}

Technology usage is also motivated by pressures from trading partners and customers because using the same technology among partners and customers facilitates the full utilisation of technology at an inter-organisational level (Low, Chen and Wu, 2011; Hameed and Counsell, 2012; Gangwar and Date, 2016 ). Here, the partnercustomer fit is defined as being fit to use Big Data Analytics as it provides a platform for sharing and analysing information among suppliers, manufacturers, wholesalers and retailers. Thus, an enhanced partner-customer 
technology fit of an organisation, leads to an increased organisational performance (in this case) by using Big Data.

H12. Partner/customer fit is positively associated with the use of Big Data Analytics.

\subsection{Perceived ease of use}

Davis (1989) defined perceived ease of use as "the degree to which using a technology would be free of effort." Extant literature suggests that perceived ease of use has a positive effect on perceived usefulness because technologies which are easy to use can be more useful and advantageous (Schillewaert et al., 2005; Wu and Chen, 2017). In the context of Big Data, the ease of use can be defined as the ease of analysing more volume and more data variety; perceived ease of use is vital for perceived usefulness and usage of Big Data.

Thus, the following hypotheses are proposed:

H13. Perceived ease of use has a positive effect on the perceived usefulness of Big Data Analytics.

H14. Perceived ease of use has a positive effect on usage of Big Data Analytics.

\subsection{Perceived usefulness}

Davis defined perceived usefulness as "the degree the prospective user's subjective probability that using a specific application system will increase his or her job performance within an organizational context." In this context, Big Data Analytics may be defined as the extent to which a person believes that this technology can be a driving force towards business decision making. Perceived usefulness is thereby a construct that has been repeatedly revealed to influence information system usage (Lee and Lehto, 2013). In addition, perceived usefulness mediates the effect of perceived ease of use on the usage of technology. Thus, the following hypothesis is proposed:

H15. Perceived usefulness has a positive effect on usage of Big Data Analytics.

\subsection{Big Data Analytics usage and business performance}

The main intention of Big Data Analytics is to enhance business performance. Hult, Hurley and Knight, (2004) defined business performance as the ability of a firm to gain profit and growth in order to achieve its general strategic objectives. Effective use of Big Data Analytics can improve efficiency of internal processes with improved decision making and have competitive offerings, implementing new strategies business models along with higher transparency of information (Murdoch and Detsky 2013; Waller and Fawcett 2013).

Thus, while the adoption intention of technology should affect performance, little research has empirically examined this link. This study thereby looked to explore the extent of influence of the use of Big Data Analytics on business performance in terms of profit, sales growth and return on investment in the Indian industry. H16 is thus formulated as:

H16. Big Data Analytics usage significantly affects business performance.

\section{Methodology}

This study investigates the use of Big Data Analytics by examining the technological fit, organisational fit, environmental fit, along with the ease of use and usefulness of technology in general. The questionnaire survey used in this study to test the theoretical model consisted of two parts: the first part included demographic questions about the participants, including the name of the company, their age, number of employees, capital, annual sales, and adoption status of Big Data Analytics services; the second part included questions measuring the constructs in the research model. Most of the variables were identified from literature and measured on a five-point Likert scale ranging from strongly disagrees to strongly agree. Considering the characteristics of Big Data, the research model consisted of 11 constructs as shown in table1. In order to assure that respondents understand the items used in the study, two consecutive rounds of pre-testing were conducted. First, the questionnaire was reviewed by academic researchers and then it was piloted with industry experts.

Using the $\mathrm{BCCl}$ (Bombay Chamber of Commerce and of Industry) database, a random sample of 1500 organisations was chosen in India. Organisations from sectors such as CPG \& Retail, Healthcare, Banking and Telecom were chosen because according to Everest research, the adoption of analytics by these sectors accounts more than $80 \%$ of the overall analytics in different sectors. These organisations were selected on the basis of questions like are they aware of Big Data, whether they are ready to use Big Data Analytics or are they already 
using it. The target participants of this study were those using Big Data. Purposeful sampling was used for data collection. Most of the responses were collected through personal visits to the respondents.

Table 1: Questionnaire development based on item from literature

\begin{tabular}{|l|l|}
\hline Task Technology Fit & Yen et al., 2010, Wu and Chen 2017 \\
\hline Individual Technology Fit & $\begin{array}{l}\text { Hung et al., 2011, Wu and Chen 2017, Gangwar, Date and } \\
\text { Ramaswamy, 2015 }\end{array}$ \\
\hline Organizational Data Fit & $\begin{array}{l}\text { Gangwar, Date and Ramaswamy, 2015, Chung et al., 2008, } \\
\text { Ramamurthy, Sen and Sinha, 2008 }\end{array}$ \\
\hline Organizational Process Fit & Schmiedel, Vom Brocke, and Recker, 2014, Gangwar, 2017 \\
\hline Organizational Strategy Fit & Gerow, Thatcher, and Grover, 2015 \\
\hline Competitive Fit & Oliveira et al., 2017, Jia, Guo and Bames, 2017 \\
\hline Partner/Customer Fit & Wang,Wang and Yang 2010, Low, Chen and Wu, 2011 \\
\hline Perceived usefulness & Wu and Chen 2017, Gangwar, Date and Ramaswamy, 2015 \\
\hline Perceive ease of use & Wu and Chen 2017, Hess, Mcnab and Basoglu, 2014 \\
\hline Big Data Analytics usage & Gangwar, 2017, Gangwar, Date and Ramaswamy, 2015 \\
\hline Business Performance & Hult, Hurley and Knight, 2004 \\
\hline
\end{tabular}

Out of 1500 organisations, 523 were found to be eligible on the basis of screened questions. Further, this study used direct interviews to collect information from the top level or the middle level IS managers in the company. Although interviewer-administered surveys are expensive and time consuming, it was preferred because it allowed us to gain a fairly good response rate. As the questions about Big Data Analytics are contemporary, this technique was useful because it enabled the interviewer to correct any ambiguities and unfold any issues raised by respondents. The study ended up with 290 usable responses for data collection. Sample characteristics are shown in table 2, table 3 and table 4.

Table 2: Categorization of firms with respect to size

\begin{tabular}{|l|l|l|}
\hline category & No of Employee & No of Organizations \\
\hline Small & No of Employee $<400$ & 87 \\
\hline Medium & $400<=$ no of Employee $<=800$ & 98 \\
\hline Large & No of Employee $>800$ & 105 \\
\hline
\end{tabular}

Table 3: Categorization of firms with respect to turnover

\begin{tabular}{|l|l|}
\hline Organization Type & No of Organizations \\
\hline CPG and Retail & 97 \\
\hline Healthcare & 56 \\
\hline Banking & 76 \\
\hline Telecom & 61 \\
\hline
\end{tabular}

Table 4: Categorization of firms with respect to sampling frame

\begin{tabular}{|l|l|}
\hline Organization Type & No of Organizations \\
\hline CPG and Retail & 97 \\
\hline Healthcare & 56 \\
\hline Banking & 76 \\
\hline Telecom & 61 \\
\hline
\end{tabular}




\section{Data analysis}

This study followed a three-step procedure in data analysis. The reliability of the questionnaire was calculated, followed by the exploratory factor analysis. Further, the fitness and construct validity of the proposed model were examined by confirmatory factor analysis, convergent validity and discriminant validity (Wu and Chen 2017). Finally, the structural model was examined to test the hypotheses.

\subsection{Reliability and exploratory factor analysis}

The reliability of the questionnaire was assessed using Cronbach's alpha. Cronbach's value for the questionnaire was 0.856 for all the multi-item constructs, which was greater than .70; this is comparable with the reliabilities reported in extant literature. Then, the scale was factor analysed using principal component analysis and Varimax rotation. The result for Bartlett's test of sphericity was 0.000 and the KMO value 0.703 , meeting the assumption for factorability. In the exploratory factor analysis, the items having factor loading more than 0.4 were retained (Chang, 2008.). After the first iteration, the item loadings were examined for their ability to explain the structure. The items which did not meet the criteria were eliminated; the factor structure thus obtained two items which did not load adequately on any factor, and three items loaded on more than one factor. In order to eliminate this ambiguity due to low-item loadings or loading of a single item on multiple factors, the factor analysis was re-run after excluding such items. In the second run, the factor loadings showed an acceptable structure and finally ten factors were extracted.

\subsection{Construct Validity}

Construct validity represent accurate measurement represented by convergent validity and discriminant validity. According to Hair, Christian and Marko, 2011 convergent validity was assessed using three criteria- All item factor loading should be more than 0.5 or higher; Construct reliability should be more than 0.7 to indicate adequate internal consistency; average variance extracted should be 0.5 or greater to indicate adequate convergent validity. Table 5 shows that the item loading, AVE, composite reliabilities and Cronbach's alpha for all the factor in the measurement model exceeded the recommended threshold values.

Discriminant validity was assessed by comparing the squared correlations between factors and their average variance extracted. Further, to test discriminant validity, the average variance of a factor should be greater than shared variance between factors (Fornell and Larcker, 1981). From Table 6 it may be inferred that the extracted average variance value for reflective variables is consistently greater than the off-diagonal squared correlations, support discriminant validity among constructs.

Table 5: Convergent Validity

\begin{tabular}{|l|l|l|l|l|}
\hline Factor & Indicators & $\begin{array}{l}\text { Standardized loadings for full } \\
\text { sample }\end{array}$ & AVE & CR \\
\hline Task Technology Fit & $\mathrm{tff}$ & 0.577 & 0.536 & 0.791 \\
\hline & $\mathrm{ttf}$ & 0.528 & & \\
\hline & $\mathrm{ttf}$ & 0.768 & & \\
\hline & $\mathrm{ttf}$ & 0.706 & & \\
\hline & $\mathrm{ttf5}$ & 0.692 & & \\
\hline Individual Technology Fit & itf1 & 0.675 & 0.545 & 0.825 \\
\hline & iff2 & 0.873 & & \\
\hline & itf3 & 0.737 & & \\
\hline & itf4 & 0.646 & & \\
\hline Organizational Data Fit & odf1 & 0.732 & 0.655 & 0.883 \\
\hline & odf2 & 0.793 & & \\
\hline & odf3 & 0.856 & & \\
\hline & odf4 & 0.849 & & \\
\hline & opf1 & 0.748 & 0.666 & 0.812 \\
\hline
\end{tabular}


The Electronic Journal of Information Systems Evaluation Volume 23 Issue 12020

\begin{tabular}{|c|c|c|c|c|}
\hline Factor & Indicators & $\begin{array}{l}\text { Standardized loadings for full } \\
\text { sample }\end{array}$ & AVE & CR \\
\hline & opf2 & 0.777 & & \\
\hline & opf3 & 0.645 & & \\
\hline & opf4 & 0.599 & & \\
\hline & opf5 & 0.626 & & \\
\hline \multirow[t]{5}{*}{ Business Strategy Fit } & bsf1 & 0.762 & 0.599 & 0.809 \\
\hline & bsf2 & 0.788 & & \\
\hline & bsf3 & 0.67 & & \\
\hline & bsf4 & 0.572 & & \\
\hline & bsf5 & 0.579 & & \\
\hline \multirow[t]{3}{*}{ Competitive Fit } & cf1 & 0.8252 & 0.594 & 0.809 \\
\hline & $\mathrm{cf} 2$ & 0.8952 & & \\
\hline & $\mathrm{cf} 3$ & 0.5492 & & \\
\hline \multirow[t]{3}{*}{ Customer/Partner Fit } & pf1 & 0.574 & 0.724 & 0.887 \\
\hline & pf2 & 0.679 & & \\
\hline & pf3 & 0.708 & & \\
\hline \multirow[t]{4}{*}{ Percieved Usefulness } & pu1 & 0.674 & 0.558 & 0.833 \\
\hline & pu2 & 0.762 & & \\
\hline & pu3 & 0.849 & & \\
\hline & pu4 & 0.688 & & \\
\hline \multirow[t]{3}{*}{ Percieved Ease of Use } & peou1 & 0.76 & 0.663 & 0.855 \\
\hline & peou2 & 0.841 & & \\
\hline & peou3 & 0.839 & & \\
\hline \multirow[t]{3}{*}{ Big Data Analytics Usage } & au1 & 0.8 & 0.705 & 0.877 \\
\hline & au2 & 0.848 & & \\
\hline & au3 & 0.869 & & \\
\hline \multirow[t]{3}{*}{ Business performance } & bf1 & 0.882 & 0.761 & 0.905 \\
\hline & bf2 & 0.844 & & \\
\hline & bf3 & 0.889 & & \\
\hline
\end{tabular}


Table 6: Inter construct Correlation

\begin{tabular}{|c|c|c|c|c|c|c|c|c|c|c|c|}
\hline & $\begin{array}{l}\text { Big } \\
\text { Data } \\
\text { Analy } \\
\text { tics } \\
\text { Usag } \\
\text { e } \\
\end{array}$ & $\begin{array}{l}\text { Busin } \\
\text { ess } \\
\text { Perfo } \\
\text { rman } \\
\text { ce }\end{array}$ & $\begin{array}{l}\text { Busin } \\
\text { ess } \\
\text { Strat } \\
\text { egy } \\
\text { Fit }\end{array}$ & $\begin{array}{l}\text { Comp } \\
\text { etitive } \\
\text { Fit }\end{array}$ & $\begin{array}{l}\text { Individu } \\
\text { al } \\
\text { Technol } \\
\text { ogy Fit }\end{array}$ & $\begin{array}{l}\text { Organi } \\
\text { zationa } \\
\text { I Data } \\
\text { Enviro } \\
\text { nment }\end{array}$ & $\begin{array}{l}\text { Organi } \\
\text { zationa } \\
\text { I } \\
\text { Proces } \\
\text { s Fit }\end{array}$ & $\begin{array}{l}\text { Part } \\
\text { ner } \\
\text { Fit }\end{array}$ & $\begin{array}{l}\text { Perce } \\
\text { ived } \\
\text { Ease } \\
\text { of } \\
\text { Use }\end{array}$ & $\begin{array}{l}\text { Perce } \\
\text { ived } \\
\text { Usefu } \\
\text { Iness }\end{array}$ & $\begin{array}{l}\text { Task } \\
\text { Tech } \\
\text { nolog } \\
\text { y Fit }\end{array}$ \\
\hline $\begin{array}{l}\text { Big } \\
\text { Data } \\
\text { Analytic } \\
\text { s Usage }\end{array}$ & 1 & & & & & & & & & & \\
\hline $\begin{array}{l}\text { Busines } \\
\text { s } \\
\text { Perform } \\
\text { ance }\end{array}$ & $\begin{array}{l}0.560 \\
5\end{array}$ & 1 & & & & & & & & & \\
\hline $\begin{array}{l}\text { Busines } \\
\text { s } \\
\text { Strategy } \\
\text { Fit }\end{array}$ & $\begin{array}{l}0.575 \\
9\end{array}$ & $\begin{array}{l}0.741 \\
7\end{array}$ & 1 & & & & & & & & \\
\hline $\begin{array}{l}\text { Competi } \\
\text { tive Fit }\end{array}$ & $\begin{array}{l}0.699 \\
9\end{array}$ & $\begin{array}{l}0.596 \\
4\end{array}$ & $\begin{array}{l}0.560 \\
1\end{array}$ & 1 & & & & & & & \\
\hline $\begin{array}{l}\text { Individu } \\
\text { al } \\
\text { Technol } \\
\text { ogy Fit }\end{array}$ & $\begin{array}{l}0.626 \\
8\end{array}$ & $\begin{array}{l}0.654 \\
5\end{array}$ & $\begin{array}{l}0.591 \\
8\end{array}$ & $\begin{array}{l}0.617 \\
7\end{array}$ & 1 & & & & & & \\
\hline $\begin{array}{l}\text { Organiz } \\
\text { ational } \\
\text { Data } \\
\text { Environ } \\
\text { ment }\end{array}$ & $\begin{array}{l}0.618 \\
1\end{array}$ & $\begin{array}{l}0.601 \\
6\end{array}$ & $\begin{array}{l}0.657 \\
8\end{array}$ & 0.616 & 0.6248 & 1 & & & & & \\
\hline $\begin{array}{l}\text { Organiz } \\
\text { ational } \\
\text { Process } \\
\text { Fit }\end{array}$ & $\begin{array}{l}0.586 \\
9\end{array}$ & $\begin{array}{l}0.772 \\
6\end{array}$ & $\begin{array}{l}0.974 \\
1\end{array}$ & $\begin{array}{l}0.572 \\
4\end{array}$ & 0.6196 & 0.6659 & 1 & & & & \\
\hline $\begin{array}{l}\text { Partner } \\
\text { Fit }\end{array}$ & $\begin{array}{l}0.660 \\
3 \\
\end{array}$ & $\begin{array}{l}0.729 \\
5 \\
\end{array}$ & $\begin{array}{l}0.666 \\
2 \\
\end{array}$ & $\begin{array}{l}0.695 \\
8 \\
\end{array}$ & 0.6526 & 0.66 & 0.6939 & 1 & & & \\
\hline $\begin{array}{l}\text { Percieve } \\
\text { d Ease } \\
\text { of Use }\end{array}$ & $\begin{array}{l}0.598 \\
2\end{array}$ & $\begin{array}{l}0.635 \\
1\end{array}$ & $\begin{array}{l}0.579 \\
7\end{array}$ & $\begin{array}{l}0.580 \\
5\end{array}$ & 0.7036 & 0.6252 & 0.6012 & $\begin{array}{l}0.60 \\
23\end{array}$ & 1 & & \\
\hline $\begin{array}{l}\text { Percieve } \\
\text { d } \\
\text { Usefulne } \\
\text { ss }\end{array}$ & $\begin{array}{l}0.680 \\
7\end{array}$ & $\begin{array}{l}0.622 \\
6\end{array}$ & $\begin{array}{l}0.632 \\
3\end{array}$ & $\begin{array}{l}0.710 \\
7\end{array}$ & 0.7268 & 0.6506 & 0.6477 & $\begin{array}{l}0.64 \\
07\end{array}$ & $\begin{array}{l}0.709 \\
2\end{array}$ & 1 & \\
\hline $\begin{array}{l}\text { Task } \\
\text { Technol } \\
\text { ogy Fit }\end{array}$ & $\begin{array}{l}0.588 \\
8\end{array}$ & $\begin{array}{l}0.615 \\
9\end{array}$ & $\begin{array}{l}0.550 \\
9\end{array}$ & $\begin{array}{l}0.607 \\
5\end{array}$ & 0.6406 & 0.6186 & 0.5817 & $\begin{array}{l}0.60 \\
61\end{array}$ & $\begin{array}{l}0.681 \\
3\end{array}$ & $\begin{array}{l}0.676 \\
7\end{array}$ & 1 \\
\hline
\end{tabular}

\subsection{Hypotheses Testing}

The 16 hypotheses presented above were tested collectively using structural equation modelling (SEM) implemented via partial least squares (PLS). A summary of the hypotheses testing results of the standardised path coefficients and path significances is provided in Table 7. Most of the paths are significant in the expected direction. Overall, 11 out of 15 hypotheses are supported by data. Task technology fit is supported to positively effect on perceived usefulness and perceived ease of use. Therefore this study supports prior studies of Klopping 
and McKinney (2004) and Wu and Chen (2017), in turn suggesting that organisational perceptions of usefulness are more dependent on technology fit to the task rather than perceptions of usefulness influenced by advantage or benefits of the technology per se. Individual technology fit is found supportive to positively affect perceived usefulness and perceived ease of use; this finding is consistent of with those of Wu and Chen (2017), indicating that fit between individual abilities and functionality of a technology increases the usefulness and makes the use of technology easier. Organisational data fit is also found to positively affect perceived usefulness and perceived ease of use. This finding is consistent with those of Chung at al. (2008) and Gangwar, Date and Ramaswamy (2015), effectively meaning that more there's a fit between organisational data environment and Big Data, the more useful Big Data Analytics can be with an unprecedented ease of use, which in turn would ensure extensive usage of this technology. The hypothesis supported the effect of process fit on perceived usefulness, wherein it has insignificant effect on perceived ease of use. Process fit increases the usefulness of Big Data Analytics because it allows Big Data Analytics to operate effectively. This is in line with Kwahk and Lee (2008) and Bazhair and Sandhu (2015) findings. Business strategy fit on the other hand is supported to positively affect perceived usefulness, which in turn, is in line with the study of Veiga, Floyd and Dechant, 2001. Competitive fit is supported to positively affect adoption intention, and is in line with Teo, Lin and Lai (2009) and Prajogo (2016) findings. Customer/partner fit is also supported to positively affect adoption intention; the results in here, are similar to those of Low, Chen and Wu (2011) and Gangwar and Date (2016). The results also showed that perceived usefulness and perceived ease of use have direct effect on the usage of Big Data, and perceived ease of use has positive effect on perceived usefulness. The relation between Big Data Analytics usage and business performance is statistically significant indicating that there's a favourable Big Data Analytics impact on return on investments.

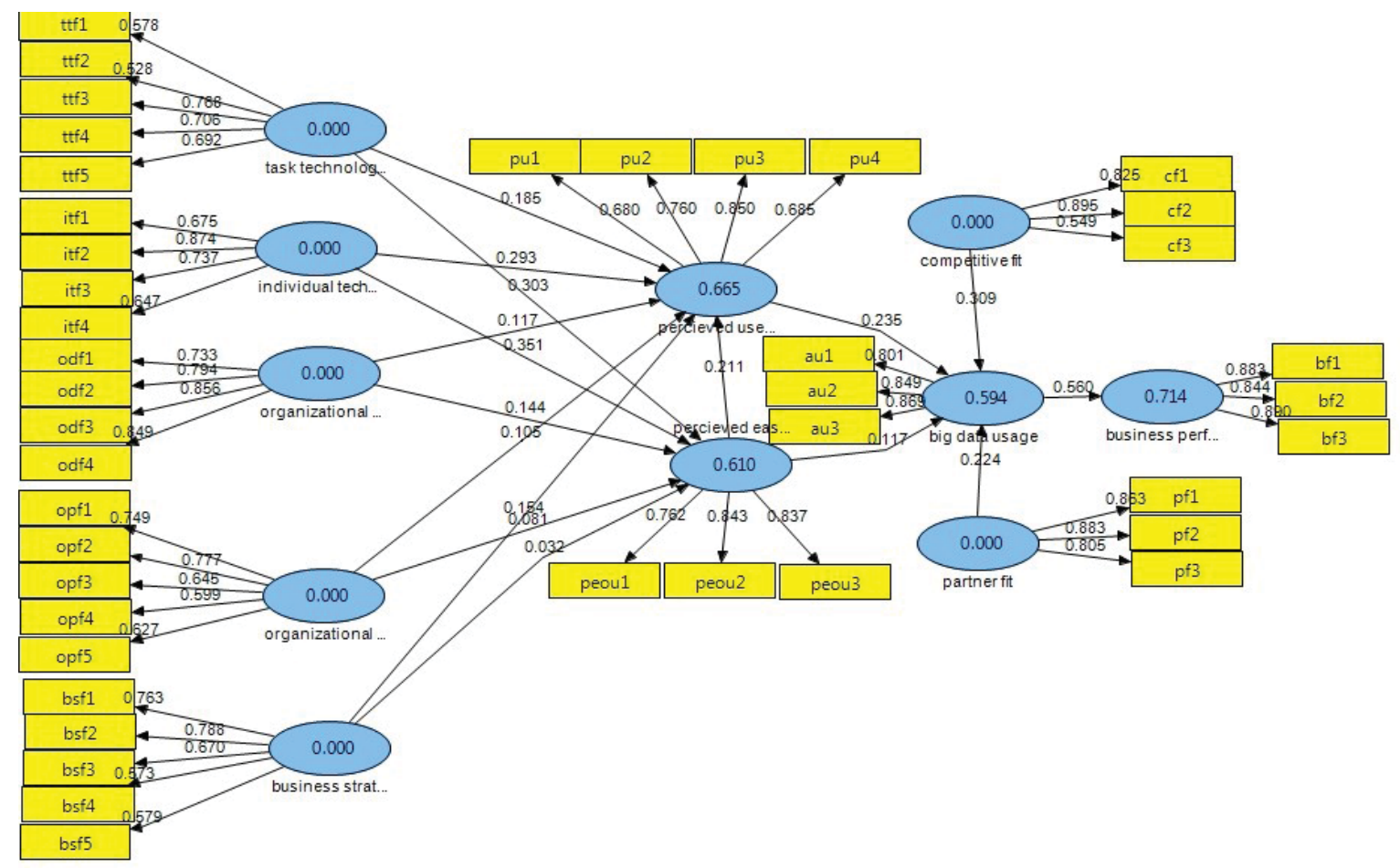

Figure 2: SEM Result 
Table 7: SEM Result

\begin{tabular}{|c|c|c|c|}
\hline & The hypothesis & Path coefficient & T value \\
\hline $\mathrm{H} 1:$ & Task-technology fit ---> Perceived usefulness & 0.185 & $5.915^{* * *}$ \\
\hline $\mathrm{H} 2$ : & Task-technology fit ---> Perceived ease of use & 0.303 & $6.5971^{* * *}$ \\
\hline H3: & Individual-technology fit ---> Perceived usefulness & 0.293 & $7.8316^{\star * *}$ \\
\hline H4: & Individual-technology fit ---> Perceived ease of use & 0.351 & $4.7109^{* * *}$ \\
\hline H5: & Organizational Data Fit ---> Perceived usefulness & 0.117 & $3.8976^{* * *}$ \\
\hline H6: & Organizational Data Fit ---> Perceived ease of use & 0.144 & $2.4273^{* *}$ \\
\hline H7: & Organizational Process Fit ---> Perceived usefulness & 0.105 & $2.2295^{\star *}$ \\
\hline H8: & Organizational Process Fit ---> Perceived ease of use & 0.08 & 0.4649 \\
\hline H9: & Business Strategy Fit ---> Perceived usefulness & 0.154 & $3.3915^{* * *}$ \\
\hline H10: & Business Strategy Fit ---> Perceived ease of use & 0.032 & 0.0368 \\
\hline H11: & Competitor Fit ---> Big Data Analytics usage & 0.309 & $5.8234^{* * *}$ \\
\hline H12: & Customer/Partner Fit ---> Big Data Analytics usage & 0.224 & $4.5221^{* * *}$ \\
\hline H13: & Perceived ease of use ---> Perceived usefulness & 0.211 & $6.0478^{* * *}$ \\
\hline H14: & Perceived ease of use ---> Big Data Analytics usage & 0.117 & $2.6504^{* *}$ \\
\hline H15: & Perceived usefulness ---> Big Data Analytics usage & 0.235 & $4.5982^{* * *}$ \\
\hline H16: & Big Data Analytics Usage ---> Business performance & 0.5605 & $16.1123^{* * *}$ \\
\hline
\end{tabular}

* Significance at $p<0.10$.

$* *$ Significance at $p<0.05$.

$* * *$ Significance at $p<0.01$.

\section{Discussion and practical implication}

The study identified task technology fit, individual technology fit, organizational data fit, process fit, and business strategy fit as important variables for affecting Big Data Analytics adoption using perceived ease of use and perceived usefulness as mediating variables; also, competitive fit and partner/customer fit were found to be directly affecting Big Data Analytics usage, which in turn was also found to explain significantly the variance in business performance.

Findings show that task technology fit has significant impact on perceived usefulness and perceived ease of use. Big Data Analytics helps organisations in analysing data for better decision making, efficiency and effectiveness of the operations. Better fit between requirement of data analysis and Big Data, can lead to greater results such as efficiency of internal processes, improved customer service, organisational competitiveness and organisational performance. It is also perceived that when the fit between task and technology is higher, user perceive easier use of technology. Therefore, managers should focus on task-technology fit, rather than the general usability of Big Data. Before offering opportunities related to an organisation's specific tasks, Big Data Analytics practitioners could ensure fits between Big Data Analytics and the organisations ' current data requirements.

Individual technology fit was found to have a strong impact on PU and PEOU, implying that an individual who holds knowledge and skill set required using Big Data, understand its usefulness and thereby find its ease of use. Big Data Analytics is easy to learn, taking lesser time in performing tasks of individuals. It identified that lesser the complexity in using Big Data, more is the enhancement in their job performance and the ease of using it. Thus mangers should provide apt training and education, which would make them well-educated, experienced, responsible and knowledgeable to effectively use this technology.

The findings also indicate that Big Data Analytics usage largely depends upon the fit between organisational and environment data in relation with this technology; better the fit between organisational, environment and Big Data, the easier would it be for the user as s/he would not need to make changes in format and work style. Big Data Analytics is found to be compatible with existing format, interface, and company policies and data architecture as a whole. 
Process fit is also found to have a significant effect on perceived usefulness; however, it is insignificant for perceived ease of use. If there is a good fit between Big Data Analytics and the business processes of an organisation, it's highly probable that the organisation would use this technology. Therefore, from the organisational viewpoint, it needs to assess the fit of Big Data Analytics with its business process through change management and a standardised set of process. Top executives of the organisation need to be able to conduct strategic and tactical plans so that organisational changes may be facilitated, and a conducive organisational culture in support of Big Data Analytics usage may be created. This study also highlights the importance of integration and customisation among various existing application with Big Data Analytics; this in turn, requires the organisation to acquire a capability to manage this technology and thereby look to customise the Big Data Analytics applications.

Further, the findings highlight that business strategy fit has a significant effect on perceived usefulness and is insignificant for perceived ease of use, effectively meaning that a well-aligned IT and business strategy can indeed go onto create a sustainable competitive advantage for the organisation as that would support the overall business objectives and thereby exploit further opportunities for growth. Poor IT planning and lack of strategic fit are likely to reduce technology performance as it is disconnected from the organisation's goal and strategy. Managers therefore should try and integrate the goals, scope and business infrastructure, and IT, rather than aligning distinct sets of strategies.

There seems to be a significant and positive relationship between competitive fit and usage of technology, in turn implying that when competitors implement Big Data Analytics as a competitive instrument, other organisations face strong competition and thereby feel the pressure of adopting new technology such as cloud computing and Big Data, just in order to maintain a competitive edge. Managers therefore need to look for ways of making technology work for their organisations even in highly competitive environments.

The findings further show that customer/partner fit is also an important parameter in Big Data Analytics usage; it implies that the usage of this technology well-integrated with the organisational value chain requires a holistic integration with customers, dealers, suppliers and partners. However, many of these trading partners could well be small organisations who perhaps, do not have the resources to fully adopt Big Data. The argument that Big Data Analytics demands integrated and electronically compatible trading systems that link firms and their trading partners to provide information exchange for one another. This often assumed worthwhile when the trading partners are big and can afford the associated costs. Therefore, managers should encourage small partner organisations to acquire modern technologies capable of improving operations.

The findings also indicate that perceived ease of use is a strong predictor of perceived usefulness, in the sense that the more Big Data Analytics is perceived as being easy to use, the more likely would organisations perceive it to be useful. The effect of perceived ease of use on perceived usefulness is more than the usage of Big Data, because organisations tend to focus on the utility of the system itself, rather than its ease of use. Therefore, perceived usefulness does serve as an important mediating variable between perceived ease of use and usage of technology; in other words, if Big Data Analytics provides the critically needed functionality, organisations do tend to accept some difficulty in its use.

Further, findings of this study indicate that Indian organisations using Big Data Analytics exhibited an increase in their business performance; managers are thereby advised to improve the usage of technology in order to attain superior business performance.

\subsection{Theoretical implication}

In this study, the application of TAM and the TTF model to Big Data Analytics is outlined, providing more precise results than individual TAM and TTF model. It also enhances our understanding of TTF as it relates to fostering Big Data. Further, TAM extended with the TTF model and organizational fit perspective. This study also seeks the fit between environmental condition and adoption intention. This study contributes to the existing literature in four ways:-

First, this study extended prior work on Big Data Analytics by highlighting the importance of achieving individualtechnology fit and task technology fit. Results show that adoption intention to use Big Data Analytics is indirectly influenced by task-technology fit, individual-technology fit, organisational data fit, process fit, business strategy fit, and finally the perceived ease of use. Further, the findings suggest that organisations are more likely to spend 
more effort in order to use Big Data, especially if they feel that doing so is beneficial in terms of task technology fit and individual technology fit. This study then goes onto highlight the importance of managing perceived usefulness and perceived ease of use through data, process and strategy right; these components increase students' perceived usefulness and perceived ease of use, which may positively affect their adoption intention of Big Data. Therefore, the relative importance of organisational fit in the proposed research model is confirmed. Thirdly, the study shows that adoption intention is also influenced by business environmental fit; environmental fit includes competitive and customer/partner acceptable, which in turn has significant effect on adoption intention. Fourth, the study explores the relationship between usage of the technology and business performance, revealing that organisations should have a goal of not just making use of the system but to make employees of the organisation satisfied with using the system in order to improve their performance, and also to empower them to make better informed decisions.

Based on the results outlined above, perceived usefulness is a critical factor affecting the adoption intention to use Big Data. Therefore, to strengthen the adoption intention to use Big Data, the factor of usefulness becomes key in enhancing Big Data Analytics services as a whole.

\section{Conclusion}

This study witnessed factors affecting Big Data Analytics usage in organisations. To underpin the basis of these factors in existing literature, the study chose technology acceptance model (TAM) for its wide acceptance in technology adoption literature. Since the introduction of the TTF Model, it has been actively researched and applied to a wide range of information systems; the uniqueness of this study is that it developed an integrated TAM-TTF framework for Big Data Analytics usage by extending TAM, using a set of variables relevant to Big Data Analytics as external variables of TAM (i.e. task technology, individual technology, organisational data, organisational process, and business strategy ), which actually have direct effect on either of the two constructs of TAM or both, and has indirect effect on Big Data Analytics usage. Thus, the two constructs of TAM act as mediating variables for external variables of TAM. Further, competitive and partner/customer were proposed to have direct impact on Big Data Analytics usage. Findings show that perceived usefulness, perceived ease of use, task technology, individual technology, organisational data, organisational process, competitive and partner/customer are important determinants for Big Data Analytics usage, which ultimately affect business performance of organisations. Also, it integrated TAM model and TTF framework using variables of TTF as external variables of TAM. The proposed hypotheses were empirically tested and results were interpreted. Further, an integrated model approach resulted in information technology adoption literature by proposing novel ways of integrating two popular adoption frameworks. This model addresses some key areas of concern as regards Big Data, and has relevance to IT professionals by enabling them to consider the areas of concern so that they can take effective course of actions while using Big Data Analytics within their respective organisations. Thus, this study is a special attempt to contribute in Big Data Analytics literature. However, this study is limited in terms of using limited set of variables and exclusion of non-adopters. Future research should validate findings of this study in other contexts. This study also has a limitation as it dealt with limited sectors in India which have substantial number of organisations who have adopted Big Data. A case based approach may be adopted at a later stage to study Big Data Analytics in sectors having limited players adopting this technology.

\section{References}

Aljukhadar, M., Senecal, S., and Nantel, J., 2014. Is more always better? Investigating the task-technology theory in an online user context. Information \& Management, 51(4), pp. 391-397.

Al-Shomrani, A., Eassa, F., Jambi, K., 2017. A Framework to Secure Big Data Storage Journal of Computational and Theoretical Nanoscience, 14(11), pp. 5600-5605.

Basoglu, N., Daim, T., and Kerimoglu, O., 2007. Organizational adoption of enterprise resource planning systems: A conceptual framework. The Journal of High Technology Management Research, 18(1), pp. 73-97.

Bates, D. W., Saria, S., Ohno-Machado, L., Shah, A., and Escobar, G., 2014. Big Data Analytics in health care: Using analytics to identify and manage high risk and high-cost patients, Health Affairs, 33(7), pp. 1123-1131,

Bazhair, A. and Sandhu, K. 2015. Factors for the Acceptance of Enterprise Resource Planning (ERP) Systems and Financial Performance. Journal of Economics, Business and Management, 3(1), pp. 1-10.

Brown, I.J.T., 2002. Individual and technological factors affecting perceived ease of use of web-based learning technologies in a developing country. EJISDC, 9(2), pp. 1-15.

Buttermann, G., Germain, R., Iyer, K.N.S., 2008. Contingency theory as gestalt: an application to supply chain management. Transportation Research Part E: Logistics and Transportation Review, 44(6), pp. 955-969.

Chang, H.H. 2008. Intelligent agent's technology characteristics applied to online auctions' task: a combined model of TTF and TAM. Technovation, 28(9), pp.564-577. 
Chaurasia, S., Rosin, Anna F., 2017. From Big Data Analytics to Big Impact: analytics for teaching and learning in higher education. Industrial and Commercial Training, 49(7/8), pp.321-328.

Chen CP., and Zhang C-Y., 2014. Data-intensive applications, challenges, techniques and technologies: a survey on Big Data. Inf Sci , 275,pp. 314-347.

Chen, H., Chiang, R., and Storey, V., 2012. Business Intelligence and Analytics: From Big Data Analyticsto Big Impact. MIS Quarterly, 36(4), pp. 1165-88

Chen, M., Mao, S., Liu, Y., 2014. Big Data: a survey, Mob. Netw. Appl. 19(2), pp.1-39.

Chung, B. Y., Skibniewski, M. J., Lucas, H. C., and Kwak, Y. H., 2008. Analyzing Enterprise Resource Planning System Implementation Success Factors in the Engineering- Construction Industry. Journal of Computing in Civil Engineering, 22(6), pp.373-382.

Coltman, T.R., Tallon, P.P., Sharma, R. and Queiroz, M. 2015. Strategic IT Alignment: Twentyfive years on, Journal of Information Technology, 30, pp.91-100

Davis, F. D. 1986. A technology acceptance model for empirically testing new end-user information systems: Theory and results. Doctoral dissertation, Sloan School of Management, Massachusetts Institute of Technology, Cambridge, MA.

Davis, F. D. 1989. Perceived usefulness, perceived ease of use, and user acceptance of information technology. MIS Quarterly, 13(3), pp.319-340.

DeLone, W.H., and McLean, E.R, 1992. Information systems success: The quest for the dependent variable. Information Systems Research, 3(1), pp.60-95.

Donaldson, L., 2001. The Contingency Theory of Organizations. SAGE Publications, Inc., Thousand Oaks.

Drnevich, P. L., and Croson, D. C. 2013. Information Technology and Business-Level Strategy: Toward an Integrated Theoretical Perspective. MIS Quarterly (37:2), pp. 483-509.

Fornell, C. and Larcker, D.F., 1981. Evaluating structural equation models with unobservable variables and measurement error. Journal of Marketing Research, 18(1), pp.39-50.

Gandomi, A., and Haider, M., 2015. Beyond The hype: Big Data Analytics concepts, methods, and analytics. International Journal of Information Management, 35(2), pp.137-144.

Gangwar, H,. Date, H., and Ramaswamy, R., 2015. Understanding determinants of cloud computing adoption using an integrated TAM-TOE model. Journal of Enterprise Information Management, 28(1), pp. 107-130

Gangwar, H., 2017. Cloud computing usage and its effect on organizational performance, Human Systems Management 36(1), pp.13-26

Gangwar, H., Date, H., 2016. Understanding cloud computing adoption: A model comparison approach. Human System Management, 35(2), pp. 13-26.

Gerow, J. E., Thatcher, J. B., \& Grover, V., 2015. Six types of IT-business strategic alignment: An investigation of the constructs and their measurement. European Journal of Information Systems, 24(5), pp.465-491.

Goodhue D.L. and Thompson, R. L., 1995. Task-technology and individual performance. MIS Quarterly, 19(2), pp.213-236.

Grandon, E., and Pearson , J.M., 2004. E-commerce adoption: perceptions of managers/owners of small and medium sized firms in Chile. Communications of the Association for Information System, 13(8), pp.81-102.

Hair, J.F., Christian M. R., and Marko S., 2011. PLS-SEM: Indeed a Silver Bullet. Journal of Marketing Theory and Practice, 19(2), pp. 139-151.

Hameed, M.A., and Counsell, S. 2012. Management \& Innovation Assessing the Influence of Environmental and CEO Characteristics for Adoption of Information Technology in Organizations. Journal of Technology Management \& Innovation, 7(1), pp.64-84.

Hashem, I.A.T., Yaqoob, I., Anuar, N.B., Mokhtar, S., Gani, A., Khan U. S., 2015

Hernandez-Ortega, B., Serrano-Cinca, C., and Gomez-Meneses, F., 2014. The firm's continuance intentions to use interorganizational ICTs: The influence of contingency factors and perceptions. Information \& Management, 51(6), pp.747-761

Hess, T. J., Mcnab, A. L., \& Basoglu, K. A., 2014. Reliability generalization of perceived ease of use, perceived usefulness, and behavioral intentions. MIS Quarterly, 38(1), pp.1-28

Hong, S., Thong, J. Y. L., and Tam, K. Y., 2006. Understanding continued information technology usage behavior: A comparison of three models in the context of mobile internet. Decision Support Systems, 42 (3), pp.1819-1834.

Hu J., and Vasilakos A., 2016. Energy Big data analytics and security: challenges and opportunities. IEEE Trans Smart Grid, 7(5), pp.2423-36.

Huang, T. C.-K., Wu, I.-L., and Chou, C.-C., 2013.Investigating use continuance of data mining tools, International Journal of Information Management, 33(5), pp.791-801.

Huang, Z., Janz, B.D. and Frolick, M.N., 2008. A comprehensive examination of internet-EDI adoption, Information Systems Management, 25(3), pp. 273-286.

Hult, G.T.M., Hurley, R.F., and Knight, G.A., 2004. Innovativeness: Its antecedents and impact on business performance. Industrial Marketing Management, 33(5), pp. 429-438.

Hung, S.Y., Chang, S.I., Yen, D.C., Kang, T.C. and Kuo, C.P., 2011. Successful implementation of collaborative product commerce: an organizational perspective. Decision Support Systems, 50(2), pp. 501-510.

Jagadish, H. V., Gehrke, J., Labrinidis, A., Papakonstantinou, Y., Patel, J. M., Ramakrishna, R., and Shahabi, C., 2014. Big Data Analytics and its technical challenges. Communications of the ACM, 57(7), pp. 86-94,

Jang, Y., and Lee, J., 1998. Factors influencing the success of management consulting projects. International Journal of Project Management, 16(2), pp. 67-72. 
Jia, Q., Guo, Y., and Barnes, S., 2017. Enterprise 2.0 post-adoption: Extending the information system continuance model based on the technology-Organization-environment framework. COMPUTERS IN HUMAN BEHAVIOR, 67, pp. 95-105.

Keller, R. T., 1994. Technology-Information Processing and the Performance of R\&D Project Groups: A Test of Contingency Theory. The Academy of Management Journal, 37(1), pp.167-179.

Khazanchi, D., 2005. Information Technology (IT) Appropriateness: The Contingency Theory of " and IT Implementation in Small and Medium Enterprises. Journal of Computer Information Systems, 45(3), pp.88-95.

Klopping, I.M. and McKinney, E., 2004. Extending the Technology Acceptance Model and the Task-Technology Model to Consumer E-Commerce. Information Technology Learning and Performance Journal, 22(1), pp.35-48.

Kshetri, N., 2014. Big Data's impact on privacy, security and consumer welfare. Telecommunications Policy, 38(11), pp.1134-1145.

Kwahk, K., and Lee, J., 1994. The role of readiness for change in ERP implementation: theoretical bases and empirical validation, Information \& Management, 45(7), pp. 474-481.

Kwon, O. Lee, N. Shin, B. 2014. Data quality management, data usage experience and acquisition intention of big data analytics. International Journal of Information Management, 34(3), pp.387-394.

Lee, D.Y. and Lehto, M.R., 2013. User Acceptance of YouTube for Procedural Learning: An Extension of the Technology Acceptance Model. Computers \& Education, 61, pp.193-208.

Lin, H. F., 2014b. Understanding the determinants of electronic supply chain management system Adoption: Using the technology organization environment framework, Technological Forecasting \& Social Change, 86, 80e92.

Lin, W.S., Wang, C.H., 2011. Antecedence to continued intentions of adopting e-learning system in blended learning instruction: a contingency framework based on models of information system success and task-technology, Computers \& Education, 58(1), pp.88-99.

Low,C., Chen,Y., Wu,M., 2011. Understanding the determinants of cloud computing adoption. Industrial Management \& Data Systems, 111(7), pp.1006-1023.

Manyika,J. Chui,M. Brown,B., Bughin, J., Dobbs, R., Roxburgh, C., Byers, A.H., 2012. Big Data: The Next Frontier for Innovation, Competition, and Productivity. McKinsey Global Institute, 2012.

McAfee, A. and Brynjolfsson, E., 2012. Big Data: The Management Revolution. Harvard Business Review, 90(10), pp.60-68.

McGill, T.J., Klobas, J.E., 2009. A task-technology view of learning management system impact. Computers \& Education, 52(2), pp.496-508.

Miller,D.,Friesen,P.H.,1982. Innovation in conservative and entrepreneurial firms: two models of strategic momentum. Strategic Management Journal, 3, pp.1-25.

Morton, N. A., and Hu, Q., 2008. Implications of the between organizational structure and ERP: A structural contingency theory perspective. International Journal of Information Management, 28(5), pp.391-402.

Murdoch TB., and Detsky AS., 2013. The inevitable application of Big Data Analytics to health care. JAMA, 309, pp.1351-2

Närman, P., Holm, H., Höök, D., Honeth, N., and Johnson, P. 2012. Using enterprise architecture and technology adoption models to predict application usage. Journal of Systems and Software, 85(8), pp.1953-1967.

Nimmagadda, S.L., Reiners, T., and Wood, L. 2018. On big-data guided upstream business research and its knowledge management, Journal of Business Research, 89, pp.143-158.

Oliveira, T. Alhinho, M. Rita, P. and Dhillon,G. 2017. Modeling and testing consumer trust dimensions in e-commerce. Computers in Human Behavior. 71, pp.153 - 164.

Pagani, M., 2006. Determinants of adoption of high speed data services in the business market: evidence for a combined technology acceptance model with task technology model. Information \& Management, 43(7), pp.847-860.

Park, Y., and Chen, J.V., 2007. Acceptance and adoption of the innovative use of smartphone. Industrial Management \& Data Systems, 107(9), pp.1349-1365.

Parkes, A. 2013. The effect of task-individual-technology on user attitude and performance: An experimental investigation. Decision Support Systems, 54(2), pp.997-1009.

Prajogo, D.I., 2016. The strategic between innovation strategies and business environment in delivering business performance. International Journal of Production Economics, 171, pp. 241-249

Ramamurthy, K., Sen, A., and Sinha, A., 2008. An empirical investigation of the key determinants of data warehouse adoption. Decision Support Systems, 44(1), pp.817-841.

Rogers, P. R., Miller, A., and Judge, W. Q., 1999. Using information-processing theory to understand planning/performance relationships in the context of strategy. Strategic Management Journal, 20(6), pp.567-577.

Ruekert, R. W., Walker, O. C., and Roering, K., 1985. The organization of marketing activities: a contingency theory of structure and performance. Journal of Marketing, 49(1), pp.13-25.

Savitz, E. 2012. Gartner: 10 Critical Tech Trends for the Next Five Years [online]. Available at: http://www.forbes.com/sites/ericsavitz/2012/10/22/gartner-10-critical-tech-trends-for-the-next-five-years/[Accessed $14^{\text {th }}$ December 2019]

Schillewaert, N., Ahearne, M. J., Frambach, R. T. and Moenaert, R. K., 2005. The adoption of information technology in the sales force. Industrial Marketing Management, 34(4), pp.323-336.

Schmiedel, T., Vom Brocke, J., \& Recker, J., 2014. Development and validation of an instrument to measure organizational cultures' support of Business Process Management. Information \& Management, 51(1), pp.43-56.

Sharma, SK., Govindaluri, SM., and AlBalushi, SM., 2015. Predicting determinants of Internet banking adoption: A twostaged regression-neural network approach. Management Research Review, 38(7), pp.750-766. 
Shin, D. H. 2016. Demystifying big data: Anatomy of big data developmental process. Telecommunications Policy, 40(9), pp.837-854.

Somal HK., 2017. Big Data Analytics \& Analytics: Tackling Business Challenges in Banking Industry. Business and Economics Journal, 8(2), pp. 305.

Sun, S., Cegielski, C. G., Jia, L. and Hall, D. J., 2016. Understanding the Factors Affecting the Organizational Adoption of Big Data. Journal of Computer Information Systems, 58(3), pp. 1-11.

Tam, C., and Oliveira, T., 2016. Performance impact of mobile banking: using the task-technology (TTF) approach. International Journal of Bank Marketing, 34(4), pp.434-457.

TEO T.S.H., and PIAN Y., 2003. A contingency perspective on internet adoption and competitive advantage. European Journal of Information Systems, 12(2), pp.78-92

Teo, T. S. H., and Men, B. 2008. Knowledge portals in Chinese consulting firms: a task-technology perspective. European Journal of Information Systems, 17(6), pp.557-574.

Teo, T. S.H., Lin, S., and Lai K-H 2009. Adopters and non-adopters of eprocurement in Singapore: An empirical study. Omega, 37(5), pp. $972-987$.

The rise of "Big Data" on cloud computing: Review and open research issues. Inf. Syst., 47 pp. 98-115

Tidd, J., 2001. Innovation management in context: environment, organization and performance. International Journal of Management Review, 3(3), pp. 169-183

Trkman, P., 2009. The critical success factors of business process management. International journal of information management, 30(2),pp. 125-134.

Tsai, K.-H., and Yang, S.-Y. 2013. Firm innovativeness and business performance: The joint moderating effects of market turbulence and competition. Industrial Marketing Management, 42(8), pp.1279-1294.

Veiga J., Floyd S., and Dechant K., 2001. Towards modeling the effects of national culture on IT implementation and acceptance. Journal of Information Technology, 16(3), pp.145-158.

Verma, S., Bhattacharyya, S. S., 2017. Perceived strategic value-based adoption of Big Data Analytics in emerging economy: A qualitative approach for Indian firms. Journal of Enterprise Information Management, 30(3), pp.354-382.

Verma, S., Bhattacharyya, S. S., and Kumar, S., 2018. An extension of the technology acceptance model in the big data analytics system implementation environment. Information Processing \& Management, 54(5), pp.791-806.

Volberda, H.W., Weerdt, N., Verwaal, E., Stienstra, M., and Verdu, A.J., 2012. Contingency, institutional, and firm performance: A meta approach to organization-environment relationships. Organization Science, 23(4), pp.10401054.

Waller, M.A., Fawcett, S.E., 2013. Data science, predictive analytics, and Big Data: A revolution that will transform supply chain design and management. Journal of Business Logistics, 34(2), pp.77-84.

Wang, Y., Wang, Y. and Yang, Y. 2010. Understanding the determinants of RFID adoption in the manufacturing industry. Technological Forecasting \& Social Change, 77(5), pp. 803-815.

Weill, P., and Olson, M., 1989. Managing Investment in Information Technology: Mini Case Examples and Implications. MIS Quarterly, 13(1), pp. 2-17.

Wixom, B.H., and Watson, H.J., 2001. An empirical investigation of the factors affecting data warehousing success. MIS Quarterly, 25(1), pp.17-41.

Wu, B. and Chen, X., 2017. Continuance intention to use MOOCs: Integrating the technology acceptance model (TAM) and task technology (TTF) model. Computers in Human Behavior, 67, pp.221-232.

Wu, W-W. 2011. Developing an explorative model for SaaS adoption. Expert Systems with Applications, 38(12), pp. 1505715064.

Wu, X., Zhu, X., Wu, G.-Q., and W, Ding. 2014. Data mining with Big Data. IEEE Transactions on Knowledge and Data Engineering, 26(1), pp.97-107.

Yang, W., and Meyer, K. E., 2015. Competitive dynamics in an emerging economy: Competitive pressures, resources, and the speed of action. Journal of Business Research, 68(6), pp. 1176-1185.

Yen, D.C., Wu, C.S., Cheng, F.F., Huang, Y.W., 2010. Determinants of users' intention to adopt wireless technology: an empirical study by integrating TTF with TAM, Comput. Hum. Behav. 26 (5), pp. 906-915

\section{Appendix A. Survey items}

\begin{tabular}{|c|c|c|c|}
\hline Construct & Items & Measures & Reference \\
\hline \multirow{4}{*}{$\begin{array}{l}\text { Task } \\
\text { Technology Fit }\end{array}$} & $\mathrm{ttf1}$ & $\begin{array}{l}\text { Using Big Data Analytics we can get quickly and easily } \\
\text { access to data when we need it. }\end{array}$ & \multirow{4}{*}{$\begin{array}{l}\text { Yen et al., 2010, } \\
\text { Wu and Chen } 2017\end{array}$} \\
\hline & ttf2 & Big Data Analytics offers accurate data for our purpose. & \\
\hline & $\mathrm{ttf3}$ & $\begin{array}{l}\text { Big Data Analytics are fit for the requirements of my data } \\
\text { analysis. }\end{array}$ & \\
\hline & $\mathrm{ttf} 4$ & $\begin{array}{l}\text { Big Data Analytics give me access to information are } \\
\text { convenient and easy to use. }\end{array}$ & \\
\hline
\end{tabular}




\begin{tabular}{|c|c|c|c|}
\hline Construct & Items & Measures & Reference \\
\hline & $\mathrm{ttf5}$ & $\begin{array}{l}\text { It is easy to get assistance when I am having trouble finding } \\
\text { or using Big Data Analytics }\end{array}$ & \\
\hline \multirow{4}{*}{$\begin{array}{l}\text { Individual } \\
\text { Technology Fit }\end{array}$} & itf1 & $\begin{array}{l}\text { Using Big Data Analytics technology fits with the way we } \\
\text { work. }\end{array}$ & \multirow{4}{*}{$\begin{array}{l}\text { Hung et al., 2011, } \\
\text { Wu and Chen 2017, } \\
\text { Gangwar, Date and } \\
\text { Ramaswamy, } 2015\end{array}$} \\
\hline & itf2 & $\begin{array}{l}\text { When we use Big Data Analytics, we find it difficult to } \\
\text { integrate my existing work with the Big Data Analytics. }\end{array}$ & \\
\hline & itf3 & $\begin{array}{l}\text { Using Big Data Analytics exposes me to the vulnerability of } \\
\text { computer breakdowns and loss of data. }\end{array}$ & \\
\hline & itf4 & $\begin{array}{l}\text { I can independently and consciously do analysis using Big } \\
\text { Data Analytics. }\end{array}$ & \\
\hline \multirow{4}{*}{$\begin{array}{l}\text { Organizational } \\
\text { Data Fit }\end{array}$} & odf1 & $\begin{array}{l}\text { Big Data Analytics is compatible with my firm's existing } \\
\text { format, interface, and other structural data. }\end{array}$ & \multirow{4}{*}{$\begin{array}{l}\text { Gangwar, Date and } \\
\text { Ramaswamy, } \\
\text { 2015,Chung et al., } \\
\text { 2008, Ramamurthy, } \\
\text { Sen and Sinha, } \\
2008\end{array}$} \\
\hline & odf2 & $\begin{array}{l}\text { There is no difficulty in importing applications/ data from Big } \\
\text { Data Analytics applications. }\end{array}$ & \\
\hline & odf3 & $\begin{array}{l}\text { There is no difficulty in exporting applications/ data from Big } \\
\text { Data Analytics applications. }\end{array}$ & \\
\hline & odf4 & $\begin{array}{l}\text { We do not have clear agreement on a common set of data } \\
\text { definitions and business rules in our company at this time. }\end{array}$ & \\
\hline \multirow{5}{*}{$\begin{array}{l}\text { Organizational } \\
\text { Process Fit }\end{array}$} & opf1 & $\begin{array}{l}\text { Our organization regularly evaluates its business processes } \\
\text { for improvement opportunities. }\end{array}$ & \multirow{5}{*}{$\begin{array}{l}\text { Schmiedel, Vom } \\
\text { Brocke, and } \\
\text { Recker, } \\
2014, \text { Gangwar, } \\
2017\end{array}$} \\
\hline & opf2 & $\begin{array}{l}\text { Our organization regularly uses performance indicators to } \\
\text { find ways to improve business processes. }\end{array}$ & \\
\hline & opf3 & $\begin{array}{l}\text { Our organization has the change management capability } \\
\text { for fit in the event of new operation flow deployment by the } \\
\text { Big Data Analytics. }\end{array}$ & \\
\hline & opf4 & Customization in Big Data Analytics is easy. & \\
\hline & opf5 & $\begin{array}{l}\text { The changes introduced by Big Data Analytics are } \\
\text { consistent with existing practices in my company. }\end{array}$ & \\
\hline \multirow{5}{*}{$\begin{array}{l}\text { Business } \\
\text { Strategy Fit }\end{array}$} & bsf1 & Our business strategies support technological innovation. & \multirow{5}{*}{$\begin{array}{l}\text { Gerow, Thatcher, } \\
\text { and Grover, } 2015\end{array}$} \\
\hline & bsf2 & Our business strategy and IT strategy align with each other. & \\
\hline & bsf3 & $\begin{array}{l}\text { Big Data Analytics strategies align with our business's } \\
\text { strategic plan. }\end{array}$ & \\
\hline & bsf4 & $\begin{array}{l}\text { We assess the strategic importance of emerging Big Data } \\
\text { Analytics technology. }\end{array}$ & \\
\hline & bsf5 & $\begin{array}{l}\text { We identify the fit between Big Data Analytics related } \\
\text { strategic opportunities and our business's strategic } \\
\text { direction. }\end{array}$ & \\
\hline
\end{tabular}


The Electronic Journal of Information Systems Evaluation Volume 23 Issue 12020

\begin{tabular}{|c|c|c|c|}
\hline Construct & Items & Measures & Reference \\
\hline \multirow{3}{*}{$\begin{array}{l}\text { Competitive } \\
\text { Fit }\end{array}$} & cf1 & $\begin{array}{l}\text { Firm thinks that Big Data Analytics has an influence on } \\
\text { competition in their industry. }\end{array}$ & \multirow{3}{*}{$\begin{array}{l}\text { Oliveira et al., } 2017 \text {, } \\
\text { Jia, Guo and } \\
\text { Bames, } 2017\end{array}$} \\
\hline & cf2 & $\begin{array}{l}\text { More and more competitors in your industry have } \\
\text { conducted team collaboration and information sharing } \\
\text { through Big Data Analytics. }\end{array}$ & \\
\hline & cf3 & $\begin{array}{l}\text { Some of our competitors have already started using Big } \\
\text { Data Analytics. }\end{array}$ & \\
\hline \multirow{3}{*}{$\begin{array}{l}\text { Customer/Part } \\
\text { ner Fit }\end{array}$} & pf1 & $\begin{array}{l}\text { The major trading partners of my company encouraged } \\
\text { implementation of Big Data Analytics. }\end{array}$ & \multirow{3}{*}{$\begin{array}{l}\text { Wang ,Wang and } \\
\text { Yang } 2010, \text { Low, } \\
\text { Chen and Wu, } 2011\end{array}$} \\
\hline & pf2 & $\begin{array}{l}\text { The major trading partners of my company recommended } \\
\text { implementation of Big Data Analytics. }\end{array}$ & \\
\hline & pf3 & $\begin{array}{l}\text { My company experienced collaboration with partner and } \\
\text { customers requires implementation of Big Data Analytics. }\end{array}$ & \\
\hline \multirow{4}{*}{$\begin{array}{l}\text { Percieved } \\
\text { Usefulness }\end{array}$} & pu1 & $\begin{array}{l}\text { Using Big Data Analytics enhances organizations } \\
\text { effectiveness. }\end{array}$ & \multirow{4}{*}{$\begin{array}{l}\text { Wu and Chen } 2017, \\
\text { Gangwar, Date and } \\
\text { Ramaswamy, } 2015\end{array}$} \\
\hline & pu2 & $\begin{array}{l}\text { Using Big Data Analytics allow me to manage business } \\
\text { operation in an efficient way. }\end{array}$ & \\
\hline & pu3 & Using Big Data Analytics improve our decision making. & \\
\hline & pu4 & $\begin{array}{l}\text { Using Big Data Analytics computing advances our } \\
\text { organizations competitiveness. }\end{array}$ & \\
\hline \multirow{3}{*}{$\begin{array}{l}\text { Percieved } \\
\text { Ease of Use }\end{array}$} & peou1 & It is easy to become proficient in using Big Data Analytics. & \multirow{3}{*}{$\begin{array}{l}\text { Wu and Chen } 2017 \text {, } \\
\text { Hess, Mcnab, and } \\
\text { Basoglu, } 2014\end{array}$} \\
\hline & peou2 & Learning to use Big Data Analytics is easy. & \\
\hline & peou3 & $\begin{array}{l}\text { My interaction with Big Data Analytics is clear and } \\
\text { understandable. }\end{array}$ & \\
\hline \multirow{3}{*}{$\begin{array}{l}\text { Big Data } \\
\text { Analytics } \\
\text { Usage }\end{array}$} & au1 & $\begin{array}{l}\text { I use Big Data Analytics in my organization very intensively } \\
\text { to support my work. }\end{array}$ & \multirow{3}{*}{$\begin{array}{l}\text { Gangwar, 2017, } \\
\text { Gangwar, Date and } \\
\text { Ramaswamy, } 2015\end{array}$} \\
\hline & au2 & $\begin{array}{l}\text { Overall I think that using Big Data Analytics is } \\
\text { advantageous. }\end{array}$ & \\
\hline & au3 & Overall, I am in favor of using the Big Data Analytics. & \\
\hline \multirow{3}{*}{$\begin{array}{l}\text { Business } \\
\text { performance }\end{array}$} & bf1 & $\begin{array}{l}\text { Big Data Analytics usage increases our firm's return on } \\
\text { investment. }\end{array}$ & \multirow{3}{*}{$\begin{array}{l}\text { Hult, Hurley and } \\
\text { Knight, } 2004\end{array}$} \\
\hline & bf2 & Big Data Analytics usage increases our firm's sales growth. & \\
\hline & bf3 & Big Data Analytics usage increases our firm's profit growth. & \\
\hline
\end{tabular}

